M.I. Baranov, S.G. Buriakovskyi, A.S. Hrytsenko, V.A. Kostiuk

\title{
RESULTS OF INVESTIGATIONS OF THERMAL RESISTIBILITY OF PROTOTYPES OF ALUMINUM ALLOY PANELS OF FUEL TANK OF AIRPLANE TO DIRECT ACTION OF NORMALIZED COMPONENTS OF ARTIFICIAL LIGHTNING CURRENT
}

Purpose. Implementation of calculation-experimental determination of thermal resistibility of walls of aluminum alloy panels of different thickness of fuel tank of the airplane designed in Ukraine to direct action on them of normalized components of current of artificial lightning. Methodology. Theoretical bases of thermophysics, bases of theoretical electrophysics, bases of measuring technique, electrophysics bases of technique of high-voltage and large pulsed currents. Results. The results of calculationexperimental investigations of thermal resistibility of prototypes with the necessary sheeting flat rectangular panels of fuel tank of the designed airplane are resulted measuring $550 \mathrm{~mm} \times 800 \mathrm{~mm}$ and from 1.2 to $4 \mathrm{~mm}$ thick of aluminum alloy B95 is easily soiled to direct action on them in obedience to the operating requirements of normative documents of the USA SAE ARP 5412 and SAE ARP 5416 of $A-, B$ - and $C *_{-}^{*}$ component of current of artificial lightning (1A area), and also $D$-, $B$ - and $C *_{-}^{*}$ components of current of artificial lightning ( $2 A$ area) with the normalized amplitude-temporal parameters (ATPs). It is determined that the tested panels of fuel tank of airplane in $1.2 \mathrm{~mm}, 1.5 \mathrm{~mm}$ and $1.8 \mathrm{~mm}$ thick for an area of $1 \mathrm{~A}$ and $1.2 \mathrm{~mm}$ and $1,5 \mathrm{~mm}$ thick for an area of $2 A$ are thermally unstable to the direct shots in them of plasma channel of a storm discharge imitated in laboratory terms with the indicated components of current of artificial lightning. It is shown that thermal resistibility to lightning of the tested panels of fuel tank of airplane is determined of ATP shortened protracted $C^{*}$ - components of current of artificial lightning, causing appearance in them of the rounded small holes of melting the radius of $r_{k}$ and depth of $h_{k}$. For finding by a calculation by the sizes of $r_{k}$ and $h_{k}$ in the indicated panels of fuel tank of airplane, struck in an air atmosphere a direct blow in them the imitated storm discharge, the proper close correlations are recommended. The capacity of these calculation correlations is confirmed results executed by the powerful high-voltage generator of impulsive current of artificial lightning of type of UITOM-1 of model experiments created in Ukraine. Originality. The calculation and experimental estimations of thermal resistibility of flat duralumin panels of fuel tank of the airplane designed in Ukraine are first executed to the direct action on them for the areas of $1 A$ and of $2 A$ of plasma channel of the imitated storm discharge with the normalized indicated documents of ATP flows on it (to the channel) $A(D)-, B$ - and $C^{*}$ - components of current of artificial lightning. Practical value. Taking into account the executed calculation-experimental investigations a practical conclusion is done that for prevention in the case of direct blow in the being in an air atmosphere airplane of plasma channel of lightning with normalized ATPs indicated components of its pulsed current of self-ignition of fuel steams in the examined duralumin tank of the designed airplane and its catastrophe the thickness of wall of an aluminum alloy B95 of this tank with the proper sheeting must make no less than $1.8 \mathrm{~mm}$ for the area of $2 \mathrm{~A}$ and no less than 2 mm for the area of $1 A$. References 19, tables 2, figures 17.

Key words: lightning, fuel tank of airplane, prototype of panel of fuel tank, thermal resistibility to lightning, components of current of lightning, generator of current of artificial lightning, calculation, experiment.

Наведено результати досліджень термічної стійкості виготовлених в заводських умовах з необхідними покриттями випробувальних зразків (В3) розміром 550 мм $\times 800$ мм і товщиною від 1,2 до 4 мм плоских панелей $з$ високоміцного алюмінієвого сплаву маркі В95 паливного бака розроблясмого вітчизняного літака до прямої дії на них для зон 1 А та $2 A$ нормованих за вимогами нормативних документів CWH SAE ARP 5412 i SAE ARP 5416 A (D)-, B- $і$ C $C^{*}-$ компонент струму штучної блискавки. Показано, що вказані В3 панелей паливного бака літака товщиною 1,2 мм, 1,5 мм і 1,8 мм для зони 1А та товщиною 1,2 мм і 1,5 мм для зони 2 А не задовольняють вимогам термічної стійкості до прямої дї̈ на них використовуваних компонент струму итучної блискавки 3 нормованими амплітудно-часовими параметрами (АЧП). Розрахунково-експериментальним иляхом із застосуванням капілярного контролю встановлено, щцо для зон 1А та 2 А пряма дія відповідних компонент струму штучної блискавки 3 нормованими АЧП на ВЗ панелей паливного бака літака вказаною товщиною призводить до ̈̈х наскрізного проплавлення, здатного викликати вибух паливної пари в баці літака, щцо розглядається, і його катастрофу. Бібл. 19, табл. 2, рис. 17.

Ключові слова: блискавка, паливний бак літака, зразок панелі паливного бака, термічна блискавкостійкість, компоненти струму блискавки, генератор струму штучної блискавки, розрахунок, експеримент.

Приведены результаты исследований термической стойкости изготовленных в заводских условиях с необходимыми зацитными покрытиями испытательных образцов (ИО) размером 550 мм $\times 800$ мм и толщиной от 1,2 до 4 мм плоских панелей из высокопрочного алюминиевого сплава марки В95 топливного бака разрабатываемого отечественного самолета к прямому воздействию на них для зон 1 и и 2 А нормированных по требованиям нормативных документов CШUA SAE ARP 5412 и SAE ARP 5416 A (D)-, В- и C - компонент тока искусственной молнии. Показано, что указанные ИО панелей топливного бака самолета толщиной 1,2 мм, 1,5 мм и 1,8 мм для зоны $1 А$ и толщиной 1,2 мм и 1,5 мм для зоны $2 A$ не удовлетворяют требованиям термической стойкости к прямому действию на них используемых компонент тока искусственной молнии с нормированными амплитудно-временными параметрами (АВП). Расчетно-экспериментальным путем с применением капиллярного контроля установлено, что для зон 1 А и 2 А прямое действие соответствующих компонент тока искусственной молнии с нормированными АВП на ИО панелей топливного бака самолета указанной толщины приводит к их сквозному проплавлению, способному вызвать взрыв топливных паров в рассматриваемом баке самолета и его катастрофу. Библ. 19, табл. 2, рис. 17.

Ключевые слова: молния, топливный бак самолета, образец панели топливного бака, термическая молниестойкость, компоненты тока молнии, генератор тока искусственной молнии, расчет, эксперимент.

Introduction. At direct strokes to aircrafts of linear lightning developing in the atmosphere of our planet with average frequency of up to 100 discharges per second

across the globe [1], the amplitude-temporal parameters (ATPs) of the flowing pulsed current as directly in the

(C) M.I. Baranov, S.G. Buriakovskyi, A.S. Hrytsenko, V.A. Kostiuk 
plasma channel of its discharge and external structural elements of the aircraft, and in the electrical circuits of the on-board radio and electrical engineering, as well as electronic equipment aircraft can take hazardous levels for electrodynamic and thermal resistibility of main devices and systems of aircraft [2]. According to the requirements of the applicable US regulatory documents SAE ARP 5412 [3] and SAE ARP 5416 [4], relating to direct lightning strikes to aerospace equipment during flight, the pulsed lightning current of the atmospheric discharge contains the following three main components: pulsed $A^{-}$, intermediate $B^{-}$and long-term $C$ components. In this case, the normalized ATPs of the pulsed $A$ - lightning current components according to $[3,4]$ take the following numerical values: current amplitude $I_{m A}= \pm 200 \mathrm{kA}$ (with tolerance of $\pm 10 \%$ ); current action integral $J_{A}=2 \cdot 10^{6} \mathrm{~A}^{2} \cdot \mathrm{s}$ (with tolerance $\pm 20 \%$ ); time $t_{m A}$ corresponding to the current amplitude $I_{m A}$ is $t_{m A} \leq 50 \mu \mathrm{s}$; duration $\tau_{p A}$ of the current flow must be equal to $\tau_{p A} \leq 500 \mu \mathrm{s}$. The aperiodic intermediate $B$ - component of the simulated lightning current has the following ATPs $[3,4]$ : average current $I_{L B}= \pm 2 \mathrm{kA}$ (with tolerance $\pm 20 \%$ ); transferred electric charge $q_{B}= \pm 10 \mathrm{C}$ (with tolerance \pm 10 $\%$ ); the duration $\tau_{p B}$ of the current flow is $\tau_{p B}=5 \mathrm{~ms}$ (with tolerance $\pm 10 \%$ ). In the case under consideration, the normalized ATPs of the aperiodic long-term $C$ - lightning current component should have the following numerical values [3, 4]: current amplitude $I_{m C}= \pm(200-800) \mathrm{A}$; transferred electric charge $q_{C}= \pm 200 \mathrm{C}$ (with tolerance $\pm 20 \%$ ); duration $\tau_{p C}$ of the current flow is $\tau_{p C}=(0.25-1)$ s. In addition, the modified (shortened) long-term $C^{*}-$ lightning current component is characterized by the following ATPs [3, 4]: average current of at least $I_{L C^{*}}= \pm 400 \mathrm{~A}$; duration $\tau_{p C^{*}}$ of the current flow is $\tau_{p C^{*}}=(15-45) \mathrm{ms}$. We point out that when simulating in laboratory conditions the total current of linear lightning and full-scale tests for lightning resistibility of an aircraft, instead of the $A$ - component, the $D$ - component can be used with the following ATPs $[3,4]$ : current amplitude $I_{m D}= \pm 100 \mathrm{kA}$ (with tolerance $\pm 10 \%$ ); current action integral $J_{D}=0.25 \cdot 10^{6} \mathrm{~A}^{2} \cdot \mathrm{s}$ (with tolerance $\mathrm{o} \pm 20 \%$ ); time $t_{m D}$ corresponding to the current amplitude $I_{m D}$ is $t_{m D} \leq 25 \mu \mathrm{s}$; duration $\tau_{p D}$ of the current flow must be equal to $\tau_{p D} \leq 500 \mu$ s.

Currently, in Ukraine and Eastern Europe countries, only the Scientific-\&-Research Planning-\&-Design Institute «Molniya» of the National Technical University «Kharkiv Polytechnic Institute» has a powerful highvoltage high-current lightning current generator (LCG) that provides reproduction of all the above components of linear lightning current with ATPs normalized by $[3,4]$ on tested for lightning resistibility objects of aviation and rocket and space technology [5-7]. This LCG of type UITOM-1 was developed and created in 2007 by the employees of the Scientific-\&-Research Planning-\&Design Institute «Molniya» of the National Technical University «Kharkiv Polytechnic Institute» [5]. Stationary LCG of type UITOM-1 with nominal energy consumption of up to 1.2 MJ (at a cost of at least USD 1.2 million [8]), which contains 5 separate high-voltage pulsed current generators (PCGs) simultaneously operating on a common electrical load for electrical voltage of $\pm 5 \mathrm{kV}$ to $\pm 50 \mathrm{kV}$ [5], is located on a high-voltage test site with area of 21 hectares of the specified Institute, geographically located in a picturesque forest $75 \mathrm{~km}$ south of Kharkiv near the urban village Andreevka.

The tasks of ensuring the electrodynamic and thermal resistibility of various aircrafts (airplanes, rocket carriers, etc.) to direct effects in the earth air atmosphere on their metal (composite) structures, airborne devices and systems of powerful lightning discharges are relevant in all industrialized countries of the world and are of great practical interest.

The goal of the paper is the calculationexperimental determination of the thermal resistibility of the walls of duralumin panels of various thicknesses of the fuel tank of the aircraft designed in Ukraine to the direct effect of normalized components of the artificial lightning current on them.

1. Problem definition. We proceed from the fact that on the tested for lightning resistibility in the discharge circuit of the indicated high-voltage highcurrent LCG of the UITOM-1 type [5] a prototype of a flat panel made of high-strength aluminum alloy grade B95 (plan size $550 \mathrm{~mm} \times 800 \mathrm{~mm}$ and wall thickness $h$ : $1.2 \mathrm{~mm} ; 1.5 \mathrm{~mm} ; 1.8 \mathrm{~mm} ; 2 \mathrm{~mm} ; 2.5 \mathrm{~mm} ; 3 \mathrm{~mm} ; 3.5 \mathrm{~mm}$; $4 \mathrm{~mm}$ ) of the fuel tank of the domestic aircraft under development with the double-sided protective coatings required by the technological requirements, a high-current plasma channel of a lightning discharge simulated under laboratory conditions for zones $1 \mathrm{~A}\left(A-, B\right.$ - and $C^{*}$ lightning current components $[3,4])$ and $2 \mathrm{~A}(D-, B$ - and $C^{*}$ - lightning current components $[3,4]$ ), for which the used components of the artificial lightning current satisfy the ATPs normalized according by $[3,4]$ act. We believe that the thermal resistibility of the test sample (TS) of the aircraft's fuel tank panel is determined by the depth $h_{k}$ of the hole (crater) of the penetration of the TS wall in the binding zone on its outer flat surface of the plasma channel of a thunderstorm discharge simulated in atmospheric air having a cylindrical shape [9]. Then the condition of thermal resistibility of the studied duralumin panels of the aircraft fuel tank to direct action on them of lightning reproduced at a high-voltage laboratory can be written in the following integral form:

$$
h_{k}<h \text {. }
$$

We believe that during the direct action of the plasma channel of a lightning discharge on the prototype of the aircraft's fuel tank panel, the rounded binding zone of radius $r_{k}$ remains almost stationary relative to the outer flat surface of the TS. We assume that the volume $V_{k}$ of TS wall's metal (alloy) molten by current of artificial lightning determines the volume and nature of the zone of its thermal damage from the action of the channel binding of this lightning discharge at the indicated location. We perform a calculated assessment of the results of the thermal effect of a simulated lightning strike to the aircraft fuel tank panel TS assuming that during this transient (no more than $50 \mathrm{~ms}$ ) shock, the thermophysical characteristics of the material of the aircraft fuel tank panel under study are unchanged. Let the temperature $T_{0}$ of the investigated TS of the panels of the fuel tank of the aircraft of the air environment be room temperature and equal to $20{ }^{\circ} \mathrm{C}$ [10]. 
We carry out experimental photo-registration of a thermal spark penetrating through the TS wall of an airplane's fuel tank panel when it is fused by a plasma channel of lightning simulated by UITOM-1 type LCG using the original technology developed by us, based on the use of an insulating light-tight camera (LTC) in the form of the correct pyramids with a height of about $1 \mathrm{~m}$ (Fig. 1). Here, in the area of the rectangular base of the pyramidal LTC, the TS is rigidly fixed using an integral rubber gasket (see Fig. 1), and in the area of its apex, a Zenit-12XP camera with a Kodak color film having a photosensitivity of at least 200 units ISO is fixed. Preliminary experimental studies have shown that in order to ignite fuel vapors in an aircraft tank, a thermal spark should emit in them (vapors) by pulsed way an energy approximately equal to at least $200 \mu \mathrm{J}$.

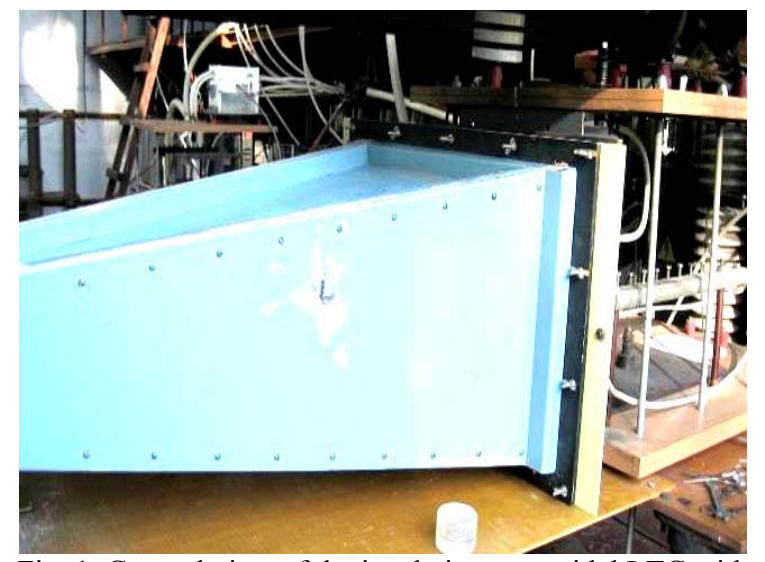

Fig. 1. General view of the insulating pyramidal LTC with vertically mounted on its end a flat panel TS of $550 \times 800 \mathrm{~mm}$ in plan and thickness of $h=3 \mathrm{~mm}$ of the aircraft's fuel tank, galvanically connected to the high-current discharge circuit of the UITOM-1 high-voltage test setup, before direct exposure to it of plasma channel discharge with a pulsed current of artificial lightning with normalized ATPs

We point out that in addition to deciphering the photo-registration data in LTC of possible sparks during thermal burn-through of the walls of the test samples by the lightning channel, their lightning resistibility after laboratory tests will, if necessary, be determined by conducting a separate capillary laboratory control in order to detect penetration of a defectoscopic penetrant at the test pulses supply points to these samples [4].

We assume that if condition (1) is met, the geometric configuration of the penetration hole of the metal on the wall of the aircraft's fuel tank panel has the shape of a round cone with a height $h_{k}$ with a base radius $r_{k}$ on the outer surface of the panel and a vertex directed inward to the wall, and if condition (1) is not fulfilled and a small through penetration (burn-through) of the wall $\left(h_{k} \geq h\right)$ of the panel under consideration from the thermal action of lightning on it, it takes the shape of a truncated round cone with a zone of its truncation on its inner surface [11]. At significant through penetration (burnthrough) of the wall $\left(h_{k}>>h\right)$ of the aircraft's fuel tank panel, the geometric configuration of its penetration hole transforms into the shape of a round cylinder [11].

We use the statement, confirmed by our own numerous experimental data, that the volume $V_{k}$, of the material of the aircraft's fuel tank panel TS molten from the direct action of the thunderstorm discharge channel the aircraft's fuel tank panel which is dangerous for local through penetration of the studied tank wall of the aircraft is determined by the long-term $C$ - or shortened long-term $C^{*}$ - components of the normalized artificial lightning current $[7,11]$. Note that from the standpoint of thermal action on structural elements of the aircraft $A(D)$ - and $B$ components of the normalized artificial lightning current cause only surface melting of the metal wall of its sheathing, which is not dangerous for the survivability of an aircraft during a thunderstorm $[7,11]$.

To initiate electric breakdown of an air gap of up to $50 \mathrm{~mm}$ in length in a two-electrode system (TES) «highvoltage electrode-TS» and the formation of an artificial lightning plasma channel in the air above the TS, we use an electrically exploding wire (EEW) $[3,4]$. As an EEW, we use a thin copper wire with a diameter of $0.1 \mathrm{~mm}$ and a length of up to $50 \mathrm{~mm}$. Between the flat surface of the TS and the edge of the EEW, we ensure that the air gap in the TES is no more than $2 \mathrm{~mm}$ long.

First, it is required to carry out, according to (1), an approximate calculation estimation of the thermal resistibility of the prototype of the indicated panel of the aircraft's fuel tank to the direct action of the simulated lightning channel on it (prototype), and then, using the UITOM-1 type LCG [5], to carry out the experimental verification of thermal lightning resistibility of the TS of the panel under consideration to direct impact of the plasma channel of artificial lightning into it.

2. Calculation estimation of the thermal resistibility of samples of aircraft's fuel tank panels to artificial lightning current. In the calculation estimation of the volume $V_{k}$ of the wall material molten by a cylindrical plasma channel with an artificial lightning current in the TS of the duralumin panel of the aircraft's fuel tank, we use the well-known relation, which has the following analytical form $[12,13]$ :

$$
V_{k}=U_{a c} q_{C} d_{0}^{-1}\left[C_{0}\left(T_{m}-T_{0}\right)+C_{m}\right]^{-1},
$$

where $U_{a c}$ is the near-electrode voltage drop in the TS zone, which plays the role of an anode electrode in the TES of the discharge circuit of the UITOM-1 type installation at a given negative polarity of $C\left(C^{*}\right)$ components, $B$ - component and the first half-waves of $A$ (D)- components of artificial lightning current, $\mathrm{V} ; q_{C}$ is the amount of electricity (charge) carried by $C\left(C^{*}\right)$ components of artificial lightning current, $\mathrm{C} ; d_{0}$ is the density of the material of the panel of the aircraft's fuel tank, $\mathrm{kg} / \mathrm{m}^{3} ; C_{0}$ is the specific heat of the material of the panel of the aircraft's fuel tank, $\mathrm{J} /\left(\mathrm{kg} \cdot{ }^{\circ} \mathrm{C}\right) ; C_{m}$ is the specific heat of fusion of the material of the panel of the fuel tank of the aircraft, $\mathrm{J} / \mathrm{kg} ; T_{m}$ is the melting temperature of the material of the aircraft's fuel tank panel, ${ }^{\circ} \mathrm{C}, T_{0}$ is the temperature of the ambient air of the $\mathrm{TS},{ }^{\circ} \mathrm{C}$.

In Table 1, in the first approximation, using the quantitative data from $[7,14,15]$, the main thermophysical characteristics for the aluminum alloy of the grade B95 of the studied experimental fuel tank panels of the aircraft under development are given. 
Table 1

Main thermophysical characteristics of the material of the experimental duralumin fuel tank panels of the designed aircraft $[7,14,15]$

\begin{tabular}{|c|c|c|}
\hline Characteristic & Dimension & Value \\
\hline$U_{a c}$ & $\mathrm{~V}$ & 8.2 \\
\hline$d_{0}$ & $\mathrm{~kg} / \mathrm{m}^{3}$ & 2790 \\
\hline$C_{0}$ & $\mathrm{~J} /\left(\mathrm{kg} \cdot{ }^{\circ} \mathrm{C}\right)$ & 920 \\
\hline$T_{m}$ & ${ }^{\circ} \mathrm{C}$ & 638 \\
\hline$C_{m}$ & $\mathrm{~J} / \mathrm{kg}$ & $390 \cdot 10^{3}$ \\
\hline
\end{tabular}

Using, to the first approximation, the conical shape of the hole (crater) for penetrating the flat wall of the aircraft's fuel tank panel with a volume of $V_{k}=\pi r_{k}^{2} h_{k} / 3$, taking into account (2) for its depth $h_{k}$ in the wall under study, from the direct thermal action of the plasma channel with radius $r_{k}$ of lightning discharge on it, we have:

$$
h_{k}=3\left(\pi r_{k}^{2}\right)^{-1} U_{a c} q_{C} d_{0}^{-1}\left[C_{0}\left(T_{m}-T_{0}\right)+C_{m}\right]^{-1} .
$$

For the estimated calculation of the radius $r_{k}(\mathrm{~m})$ of the simulated lightning discharge channel with shortened long-term $C^{*}$ - component of the lightning current in its rounded supporting zone on the outer flat surface of the studied panel of the aircraft's fuel tank, we use the following empirical dependence $[7,16]$ :

$$
r_{k}=0,11 \cdot 10^{-3}\left(I_{m C^{*}}\right)^{1 / 2},
$$

where $I_{m C^{*}}$ is the modulus of the maximum current for the shortened long-term $C^{*}$ - component of the artificial lightning current in the plasma cylindrical channel of the discharge, which transfers the electric charge $q_{C^{*}}$.

Then, regarding the flow in the channel of artificial lightning of the shortened long-term $C^{*}$ - current component, from (3), (4) for the depth $h_{k}(\mathrm{~m})$ of the conical penetration hole in the wall of the studied panel of the aircraft's fuel tank, we obtain in the final form the following approximate relationship:

$$
h_{k}=78,92 \cdot 10^{6}\left(I_{m C^{*}} d_{0}\right)^{-1} U_{a c} q_{C^{*}}\left[C_{0}\left(T_{m}-T_{0}\right)+C_{m}\right]^{-1} \text {. }
$$

To evaluate the working capacity at $T_{0}=20^{\circ} \mathrm{C}$ of the obtained calculation relationship (5), which determines, at a direct lightning strike on an aircraft, the depth $h_{k}$ of the penetration hole in the wall of the considered flat panel of its fuel tank, we use the numerical data given in Table 1, as well as the following initial parameters corresponding to the conditions for conducting thermal tests for lightning resistibility of the TS for zones $1 \mathrm{~A}$ and $2 \mathrm{~A}$ using the UITOM-1 type installation: $I_{m C^{*}}=1000 \mathrm{~A} ; q_{C^{*}}=6.1 \mathrm{C}$. After substituting the indicated initial data in (5), we find that the sought value $h_{k}$ assumes a numerical value equal to approximately $1.48 \mathrm{~mm}$. From this, taking into account (1) and the calculation estimation for $h_{k}$ carried out according to (5), for determining the thermal resistibility of a plane panel with thickness $h$ of the aircraft's fuel tank to a direct impact to it of a lightning discharge channel with shortened long-term $C^{*}$ - component of the artificial lightning current, we can preliminary conclude that tested duralumin panels of the indicated tank with wall thickness $h$ of $1.2 \mathrm{~mm}$ and $1.5 \mathrm{~mm}$ with high probability, and with $h=1.8 \mathrm{~mm}$ with a possible degree of probability may not satisfy the accepted condition of their thermal resistibility to normalized pulsed lightning current action.
3. Equipment for experimental verification of thermal lightning resistibility of samples of aircraft's fuel tank panels. This verification is feasible by placing the indicated TS of duralumin panels of the fuel tank of the aircraft into the gap of the high-current discharge circuit of the LCG of type UITOM-1, general view of which is shown in Fig. 2.

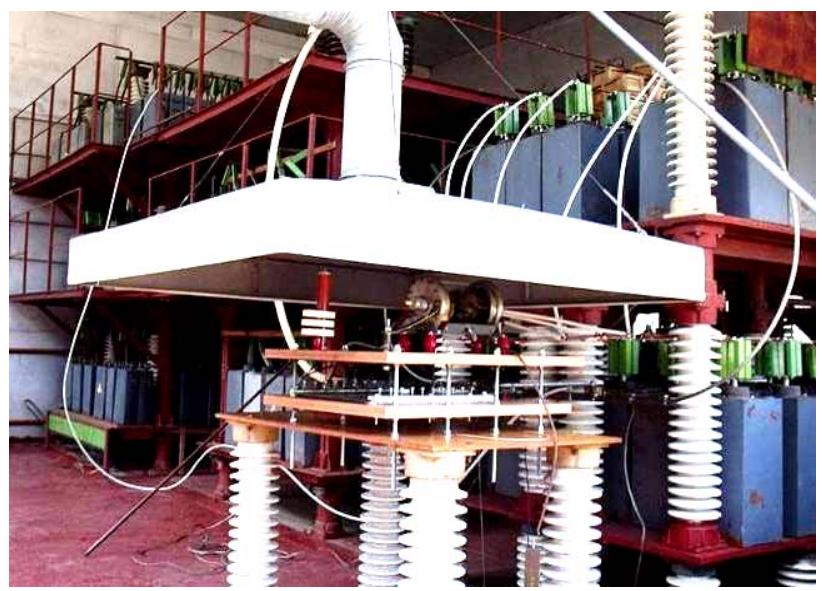

Fig. 2. General view of a high-voltage high-current test facility of the type UITOM-1 (developed by the Scientific-\&-Research

Planning-\&-Design Institute «Molniya» of the National

Technical University «Kharkiv Polytechnic Institute») which

simulates the direct effect of the main components of the

artificial lightning current on the TS of the metal panel of a domestic aircraft's fuel tank (in the foreground is a desktop with a three-electrode controlled air switch for voltage of $\pm 50 \mathrm{kV}$ and an air exhaust system, and in the background are powerful highvoltage generators PCG- $A$, PCG- $D$, PCG- $B$, PCG- $C$ and $\left.\mathrm{PCG}-C^{*}\right)[5,6]$

Figure 3 shows the electrical equivalent circuits of the discharge circuits of five powerful high-voltage generators (PCG- $A$, PCG- $D$, PCG- $B$, PCG- $C$ and PCG$\left.C^{*}\right)$ of the UITOM-1 type test facility, modeling respectively $A-, D-, B-, C$ - and $C^{*}$ - components of the artificial lightning current and synchronously operating on a common low-inductance and low-resistance concentrated $R_{L} L_{L}$ load $\left(R_{L}=50 \mathrm{~m} \Omega ; L_{L}=1 \mu \mathrm{H}\right)$ [5, 6]. It can be seen that in the discharge circuit of the LCG used, the active resistance $R_{S}=0.158 \mathrm{~m} \Omega$ of the low-resistance measuring shunt of the ShK-300M1 type, which passed the state metrological certification at the State Enterprise «Kharkiv Standard Metrology» (certificate of verification of measuring equipment No. 06/4113 of April 14, 2017) is connected in series with the indicated electrical load equivalent. Table 2 shows the main technical characteristics of the shunt type ShK-300M1 [7, 17].

Figure 4 shows general view of a measuring disk coaxial shunt of the ShK-300M1 type, and Fig. 5 presents a view of this shunt assembly with shielded coaxial communication line of the measuring path and SDN-300 voltage divider matched on to this path, the coaxial connectors $1: 1$ and 1:2 of which are connected to the coaxial inputs of three digital storage oscilloscopes (DSO) for recording ATPs of $A(D)$-, $B$ - and $C\left(C^{*}\right)$ - components of the current of artificial lightning. Oscilloscopes of the Tektronix TDS 1012 type, which were metrologically 
verified by the State Enterprise «Kharkiv Standard Metrology» (for example, calibration certificate No. $08 / 2128 \mathrm{~K}$ of 05.16 .2017 ) and placed in a buried measuring metal bunker remote from the UITOM-1 installation for reduce the influence of interference at a distance of $60 \mathrm{~m}[7,17]$ have been used as DSO.

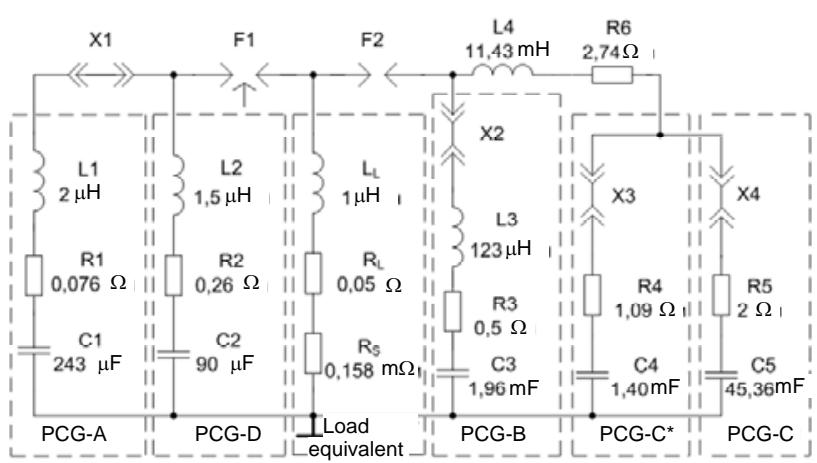

Fig. 3. Electrical equivalent circuits for the discharge circuits of five separate high-voltage PGSs (PCG- $A$, PCG- $D$, PCG- $B$,

PCG- $C$ and PCG- $C^{*}$ ) and a powerful LCG type UITOM- 1 as a whole with one common electric active-inductive $R_{L} L_{L}$ load (F1,

F2 - three- and two-electrode high-current air switches for voltage $\pm 50 \mathrm{kV}$ and $\pm 5 \mathrm{kV}$, respectively; X1-X4 - electrical jumpers; $R_{S}=0.158 \mathrm{~m} \Omega$ - active resistance of a measuring coaxial shunt of type ShK-300M1; R1-R5, L1 -L3 - own electrical parameters of the circuits of PCG- $A$, PCG- $D$, PCG- $B$, PCG- $C^{*}$ and PCG- $C$; R6, L4 - electric of forming elements for circuits of PCG-C and PCG- $\left.C^{*}\right)[5,6]$

Table 2

Technical characteristics of the high-voltage high-current measuring shunt ShK-300M1 [17, 18]

\begin{tabular}{|c|c|c|c|}
\hline \multirow{2}{*}{ Shunt name } & \multicolumn{3}{|c|}{ Characteristic's value } \\
\cline { 2 - 3 } & $R_{S}, \mathrm{~m} \Omega$ & $K_{S}, \mathrm{~A} / \mathrm{V}$ & Mass, $\mathrm{kg}$ \\
\hline \multirow{2}{*}{ ShK-300M1 } & \multirow{2}{*}{$0.158 \pm 1 \%$} & $K_{S A}=12625$ & \multirow{2}{*}{3.1} \\
\cline { 3 - 3 } & & $K_{S C}=6312$ & \\
\hline
\end{tabular}

Note. $K_{S}=2 / R_{S}$ is the shunt conversion coefficient, $\mathrm{A} / \mathrm{V} ; K_{S A}$ is the shunt conversion coefficient when measuring in the LCG discharge circuit of ATPs of $A$ - and $D$ - components of artificial lightning current, $\mathrm{A} / \mathrm{V}$ (from the 1:1 coaxial connector of a special voltage divider (SVD) type SDN-300); $K_{S C}$ is the shunt conversion coefficient when measuring in the LCG discharge circuit of the ATPs of $B-, C$ - and $C^{*}$ - components of the artificial lightning current, $\mathrm{A} / \mathrm{V}$ (from the 1:2 coaxial connector of the SDN-300 voltage divider matched on)

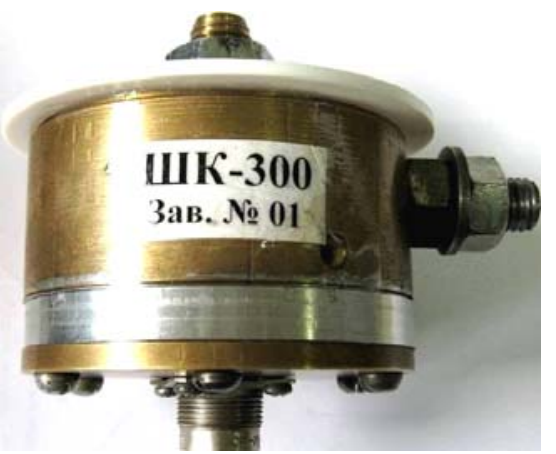

Fig. 4. General view of a measuring disk shunt of a coaxial design of the ShK-300M1 type, installed in a high-current discharge circuit of a high-voltage test setup of the UITOM-1 type and used for simultaneous recording on the screens of three

storage oscilloscopes of ATPs of $A(D)$-, $B$ - and $C\left(C^{*}\right)$ components of the artificial lightning current $[17,18]$

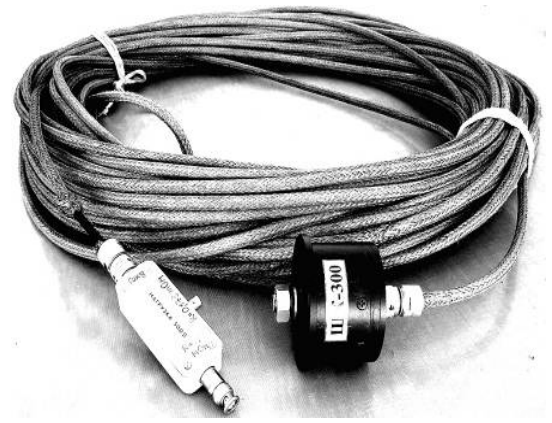

Fig. 5. General view of the measuring disk coaxial shunt of the ShK-300M1 type assembled with a shielded triaxial cable communication line (70 m long) and a matched on special

voltage divider of the SDN-300 type with two coaxial connectors $1: 1$ and $1: 2$ connected by short pieces of cable to the coaxial inputs of the corresponding digital storage oscilloscopes $[7,17]$

Data in Fig. 3 shows that in the discharge circuits of the PCG- $A$ and PCG- $D$ generators a controlled threeelectrode air switch $F_{1}$ with massive steel electrodes for voltage of $\pm 50 \mathrm{kV}$ is installed, and in the discharge circuits of the PCG- $B$, PCG- $C$ and PCG- $C^{*}$ generators, there is a two-electrode air switch $F_{2}$ with graphite electrodes for voltage of $\pm 5 \mathrm{kV}[5,19]$. After a simultaneous charge from two parallel-operating from a single-phase industrial network with frequency of $50 \mathrm{~Hz}$ of the boost-rectifier devices of the high-voltage capacitors of the corresponding PCGs of the UITOM-1 test facility to the required by the conditions of obtaining in the TS of necessary by [3, 4] ATPs of the current pulses of artificial lightning of constant electric voltage of negative polarity (for capacitors of the PCG- $A$ and PCG$D$ up to voltage $U_{C A}$ in the range $-(21-21.5) \mathrm{kV}$; for capacitors of the PCG- $B$ and PCG- $C^{*}$ up to voltage $U_{C C}$ in the range $-(3.1-3.8) \mathrm{kV})$ and feeding from a special generator developed by the Scientific-\&-Research Planning-\&-Design Institute «Molniya» of the National Technical University «Kharkiv Polytechnic Institute» of an igniting microsecond voltage pulse of negative polarity with amplitude of up to $100 \mathrm{kV}[5,19]$ to switch $F_{1}$ (see Fig. 3) there was a high-current discharge of pre-charged high-voltage capacitors of the applied PCG generators on the outer flat surface of the aircraft's fuel tank panel TS.

Figure 6 shows the test circuit of the UITOM-1 type high-voltage installation, corresponding to the case of using for the purposes of experimental verification of lightning resistibility of the TS of the fuel tank panels of the aircraft to the effects on them only of $C^{*}$ - component of artificial lightning current from the PCG- $C^{*}$.

An experimental determination of the lightning resistibility of the TS of the fuel tank panels of the aircraft at the direct influence of the plasma channel of the simulated lightning discharge on them was carried out on the indicated UITOM-1 type test setup containing four indicated PCGs (see Fig. 3). Moreover, when modeling for the purpose of testing the TS of the artificial lightning current pulses for zone 1A, three parallel operating PCGs were used: PSG- $A$, PCG- $B$ and PCG- $C^{*}$. During the reproduction of simulated pulsed lightning currents during the TS test for zone $2 \mathrm{~A}$, the following three parallel operating PCGs: PCG- $D$, PCG- $B$ and PCG- $C^{*}$ were used. 


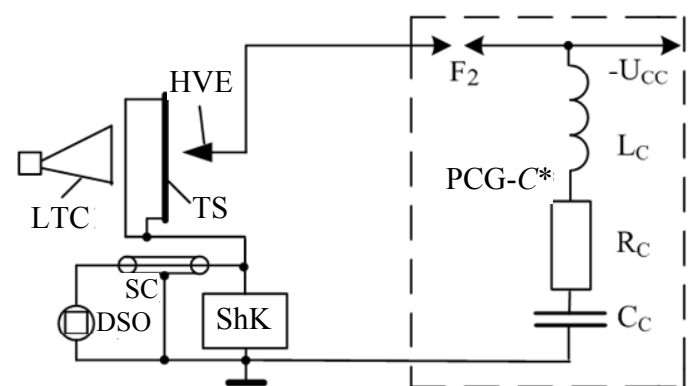

Fig. 6. A test circuit using a high-voltage high-current installation of the UITOM-1 type to determine the lightning resistibility of prototypes of flat panels of a fuel tank of a domestic aircraft at direct exposure to them of air lightning discharge from PCG, simulating only the modified (shortened)

long-term $C^{*}$ - component of the artificial lightning current (PCG- $C^{*}$ - generator, reproducing $C^{*}$ - component of lightning current; TS - test sample; HVE - high-voltage electrode, on which an electrically exploding thin copper wire is fixed; LTC light-tight camera for photographic recording of a thermal spark; SC - shielded cable of a coaxial communication line; DSO digital oscilloscope; ShK - disk coaxial shunt for measuring

ATPs of artificial lightning current pulses having an active resistance of $R_{S}=(0.158 \pm 0.001) \mathrm{m} \Omega$ and conversion coefficients

$K_{S}$ equal to $12625 \mathrm{~A} / \mathrm{V}$ (for measuring the $A$ - and $D$ -

components of the lightning current) and $6312 \mathrm{~A} / \mathrm{V}$ (for measuring the $B$ - and $C^{*}$ - components of the lightning current); $R_{C} \approx 3.83 \Omega, L_{C} \approx 11.43 \mathrm{mH}, C_{C} \approx 1.4 \mathrm{mF}$ - electrical parameters of the PCG- $C^{*}$ discharge circuit; $F_{2}$ - PCG- $C^{*}$ two-electrode air switch for voltage $\pm 5 \mathrm{kV}$ with graphite electrodes, controlled in operation by applying an igniting microsecond voltage pulse with an amplitude of $-100 \mathrm{kV}$ to a three-electrode air switch $F_{1}$ (voltage $\pm 50 \mathrm{kV}$ ) in the discharge circuit of PCG- $A$ (PCG- $D$ );

$$
U_{C C} \text { - PCG- } C^{*} \text { charging voltage) }
$$

Estimation of the lightning resistibility of the TS of the aircraft's fuel tank panels after feeding them of required in accordance with the recommendations specified in the US documents SAE ARP 5412 [3] and SAE ARP 5416 [4] current pulses of artificial lightning was carried out by:

- external inspection of the TS of the panels of the aircraft's fuel tank in order to determine the integrity of their structure in the zone of direct impact in them of the lightning channel;

- photo-recording with the help of the LTC and a camera (Fig. 7) of possible thermal sparks from the internal flat surface of the TS during direct exposure from the above-mentioned high-voltage PCG generators of the UITOM-1 type test installation to their external surface of the corresponding current pulses of artificial lightning for zones $1 \mathrm{~A}$ and $2 \mathrm{~A}$;

- carrying out, after high-voltage high-current tests of pilot duralumin panels on the LCG of the type UITOM-1, of capillary control of the TS.

4. Test results for thermal lightning resistibility of samples of aircraft's fuel tank panels for zones $1 \mathrm{~A}$ and $2 \mathrm{~A}$. Figure 8 shows general view of the TS of the panel being examined for lightning resistibility $(h=3 \mathrm{~mm})$ of the aircraft's fuel tank immediately after direct exposure to it of the full normalized current of artificial lightning, characteristic of zone 1A. Experimental verification at the UITOM-1 type LCG (see Fig. 2) of the thermal lightning resistibility of the TS of flat panels $4 \mathrm{~mm}, 3.5 \mathrm{~mm}, 3 \mathrm{~mm}, 2.5 \mathrm{~mm}, 2 \mathrm{~mm}, 1.8 \mathrm{~mm}$ and

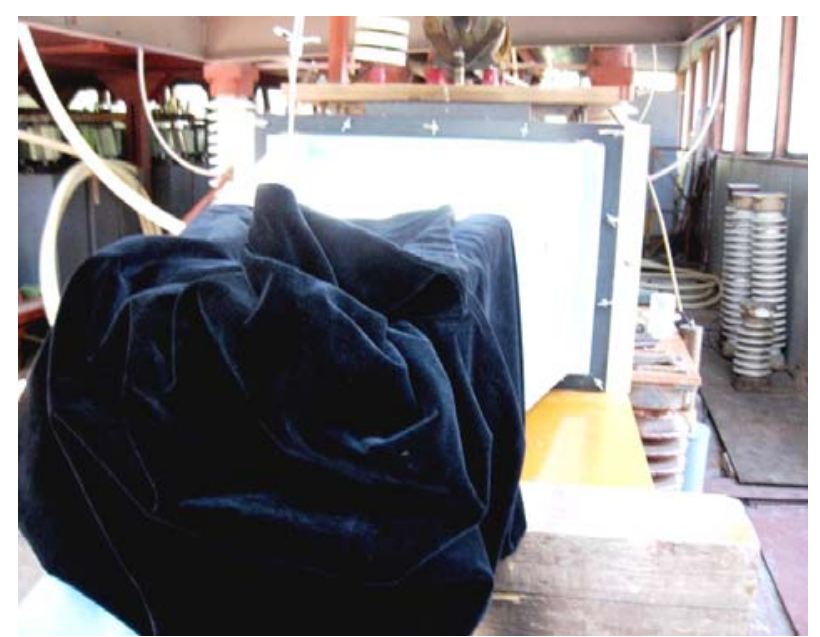

Fig. 7. Appearance of a pyramidal LTC with a camera at its small end (the camera is covered with a black lightproof protective cover) during the current registration of thermal sparks from the internal surface of the TS, rigidly and vertically mounted on its large end

$1.5 \mathrm{~mm}$ thick of the aircraft's tank for zones $1 \mathrm{~A}$ and $2 \mathrm{~A}$ showed that through penetration of their walls was not visually observed.

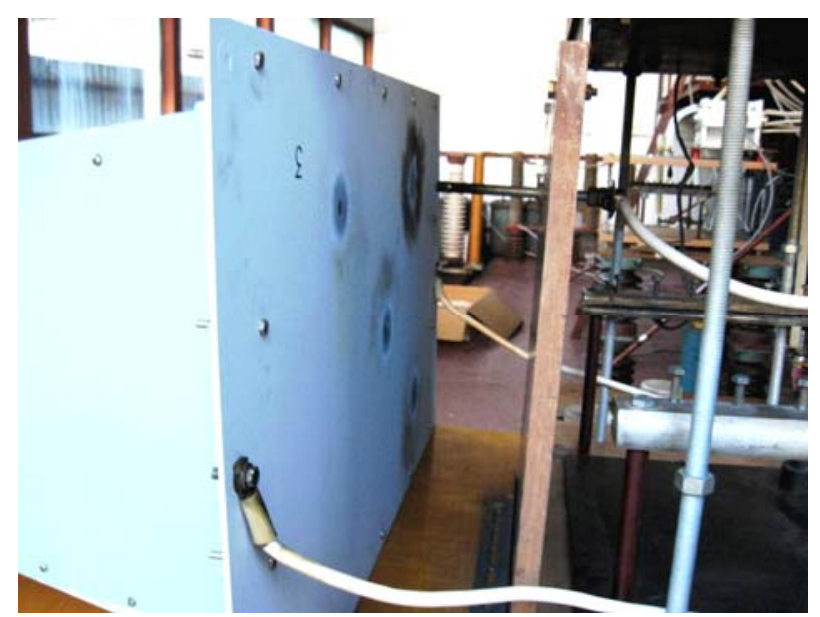

Fig. 8. General view of the TS of a flat panel with a plan size of $550 \times 800 \mathrm{~mm}$ (thickness $h=3 \mathrm{~mm}$ ) of the aircraft's fuel tank, vertically mounted on the end face of an insulating LTC and connected by flexible massive copper buses to a high-current discharge circuit of the UITOM-1 high-voltage test setup, immediately after direct exposure to it (top right) of the plasma channel of the discharge with pulsed current of artificial lightning simulating the direct thermal effect on the TS of normalized current pulses of the air lightning discharge for zone $1 \mathrm{~A}$

The later processing of films from the camera mounted on the end of the LTC and recording possible thermal sparks from the inner surface of the TS of the panels showed that there were no thermal points or sparking on the inside of these panels either. At direct impact on the indicated TS of the aircraft's fuel tank panels of the plasma high-current channel of artificial lightning current with normalized ATPs of its $A(D)-, B$ and $C^{*}$ - component, there was only local fusion of the outer surface of the TS in the binding zone on it of this high-current channel of air simulated lightning discharge with the formation, firstly, of a rounded molten hole 
(from the action of $A(D)$ - lightning current component) with a diameter of up to $60 \mathrm{~mm}$ and a shallow depth (up to 50 microns) and, secondly, of a central rounded reflow crater (from the action of $C^{*}$ - lightning current components) with a diameter of up to $7.4 \mathrm{~mm}$ and a depth of up to $1.5 \mathrm{~mm}$.

The experimental results of the laboratory capillary inspection of the TS conducted later by the personnel of the special unit of Antonov Company revealed the penetration of a defectoscopic penetrant through duralumin panels $1.5 \mathrm{~mm}$ and $1.8 \mathrm{~mm}$ thick tested for zone $1 \mathrm{~A}$, and also through duralumin panels tested for zone $2 \mathrm{~A}$ with thickness $h=1.5 \mathrm{~mm}$. These results indicate the presence in the TS of through defects for the indicated cases.

The above experimental results correlate well with the calculated data obtained by (4) for radius $r_{k} \approx 3.6 \mathrm{~mm}$ (at $I_{m C^{*}}=1110 \mathrm{~A}$ ) and according to (5) for depth $h_{k} \approx 1.4 \mathrm{~mm}$ (at $q_{C^{*}}=6.4 \mathrm{C}$ ) of a rounded penetration hole of a wall of tested on the described powerful high-voltage high-current LCG type UITOM-1 the flat duralumin panel of the fuel tank of the designed aircraft.

Figures 9-11 show the oscillograms of the artificial lightning current components typical for zone $1 \mathrm{~A}$ that act in the discharge circuit of the LCG type UITOM-1 on the IO of thickness $h=1.5 \mathrm{~mm}$ of the flat duralumin panel of the aircraft's fuel tank. A visual examination of this TS after testing it in the LCG circuit for thermal lightning resistibility (Fig. 12) did not give direct results on the presence of through penetration in its wall from a direct impact of the simulated lightning current components $A$-, $B$ - and $C^{*}$ - with normalized ATPs. Only the further application of the method of capillary control of the place of thermal damage to the TS for zone 1A confirmed the presence of through penetration of the wall of the duralumin panel with thickness $h=1.5 \mathrm{~mm}$ of the aircraft's fuel tank.

Figures 13-15 show the oscillograms of the artificial lightning current components typical for zone $2 \mathrm{~A}$ that act in the UITOM-1 type LCG discharge circuit on the TS with thickness $h=1.5 \mathrm{~mm}$ of a flat duralumin panel of the aircraft's fuel tank. From the data of a visual inspection of this TS, it follows that for zone $2 \mathrm{~A}$, the $D$-, $B$ - and $C^{*}$ - components of the artificial lightning used in tests of the TS of thickness $h=1.5 \mathrm{~mm}$ of the plane duralumin panel of the aircraft's do not cause through penetration of its wall visible to the naked eye. This is also evidenced by the registration results for zone $2 \mathrm{~A}$ with the help of a camera installed in the LTS of possible thermal sparks from the inner surface of the TS with thickness $h=1.5 \mathrm{~mm}$ of its wall. At the same time, the possible through penetration in this case of the wall under consideration with thickness $h=1.5 \mathrm{~mm}$ of the aircraft's fuel tank is indicated by the calculated data by (5) for the depth $h_{k} \approx 1.3 \mathrm{~mm}$ (at $q_{C^{*}}=6.16 \mathrm{C}$ ) and according to (4) for radius $r_{k} \approx 3.7 \mathrm{~mm}$ (at $I_{m C^{*}}=1148 \mathrm{~A}$ ) of the rounded hole of its penetration due to the action of the lightning channel on it.

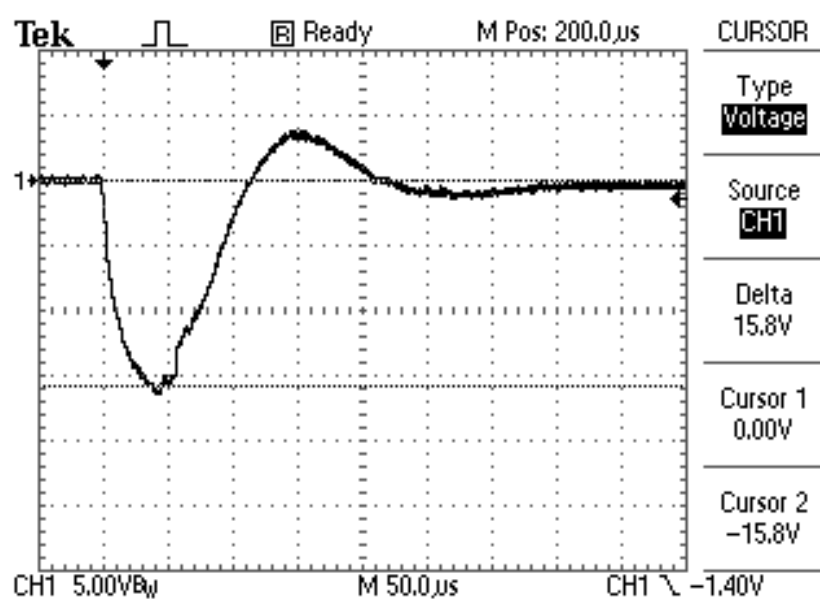

Fig. 9. Oscillogram of the pulsed $A$ - component of the current of artificial lightning acting on the TS (point 5', zone 1A) of thickness $h=1.5 \mathrm{~mm}\left(I_{m A}=-15.8 \mathrm{~V} \times 12625 \mathrm{~A} / \mathrm{V}=-199.5 \mathrm{kA}\right.$; $\left.t_{m A}=42 \mu \mathrm{s} ; J_{A}=1.98 \cdot 10^{6} \mathrm{~A}^{2} \cdot \mathrm{s}\right)$

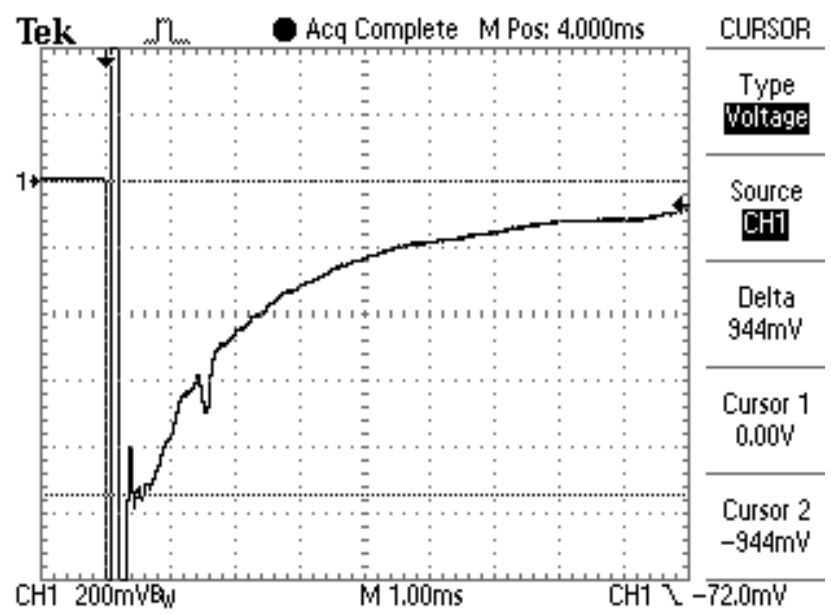

Fig. 10. Oscillogram of the intermediate $B$ - component of the current of artificial lightning acting on the TS (point 5 , zone $1 \mathrm{~A}$ ) of thickness $h=1.5 \mathrm{~mm}\left(I_{m B}=-0.944 \mathrm{~V} \times 6312 \mathrm{~A} / \mathrm{V}=-5958 \mathrm{~A}\right.$; $I_{L B}=q_{B} / \tau_{p B}=-2400 \mathrm{~A} ; \tau_{p B}=5 \mathrm{~ms} ; q_{B}=-12 \mathrm{C}$ )

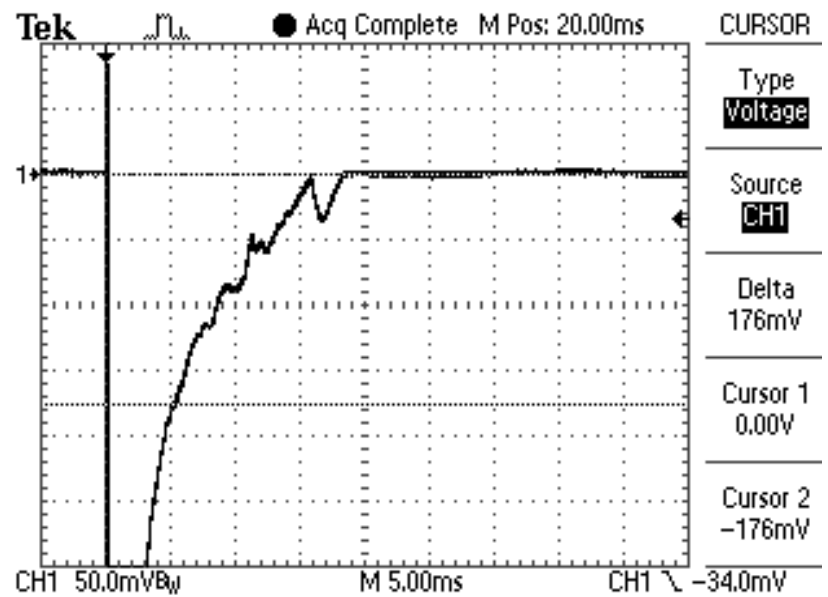

Fig. 11. Oscillogram of the shortened long-term $C^{*}$ - component of the current of artificial lightning acting on the TS (point 5', zone 1A) of thickness $h=1.5 \mathrm{~mm}$

$\left(I_{m C^{*}}=-0.176 \mathrm{~V} \times 6312 \mathrm{~A} / \mathrm{V}=-1111 \mathrm{~A} ; I_{L C^{*}}=q_{C^{*}} / \tau_{p C^{*}}=426 \mathrm{~A}\right.$; $\tau_{p C^{*}}=13.6 \mathrm{~ms} ; q_{C^{*}}=-5.79 \mathrm{C}$ ) 


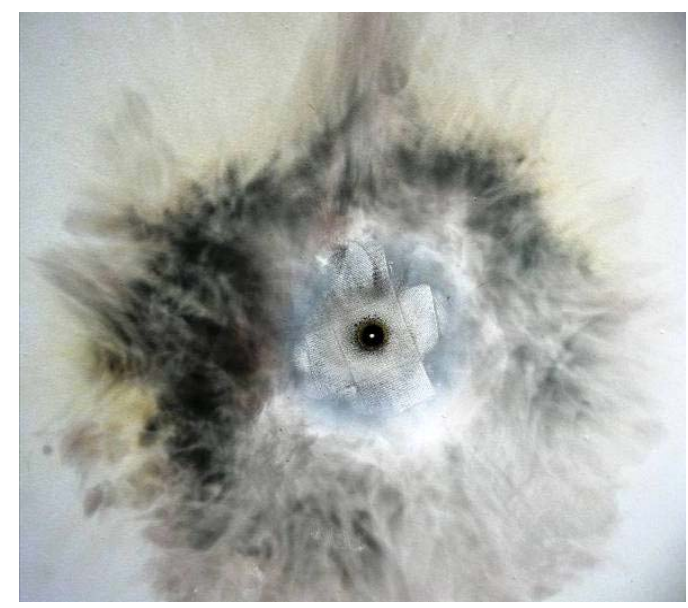

Fig. 12. General view from the binding zone on the outer surface of the TS of a flat duralumin panel $(h=1.5 \mathrm{~mm})$ of the airplane's fuel tank of the plasma channel simulated at the UITOM-1 type installation of the lightning discharge of the results of the direct impact on this TS for zone 1A of the normalized components of the artificial lightning current, characterized by local thermal damage of the wall of the TS of the panel at the place of impact of the lightning channel to it

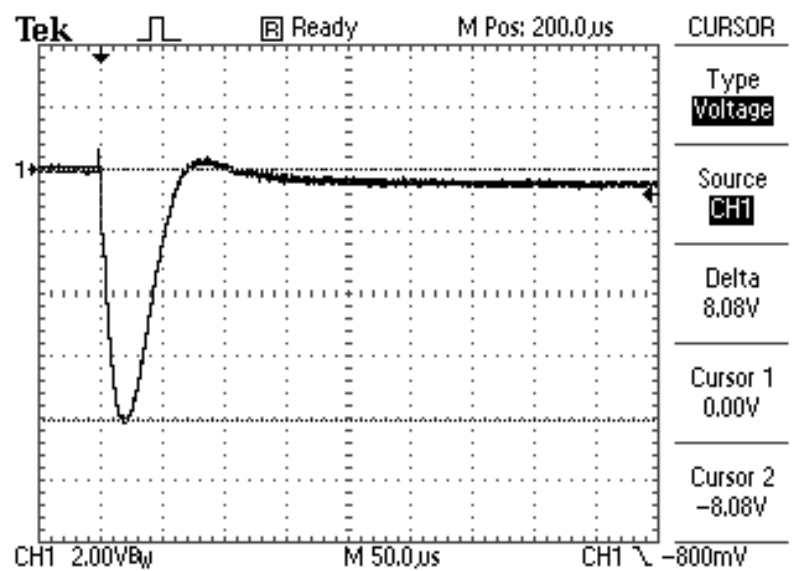

Fig. 13. Oscillogram of the repeated pulsed $D$ - component of the lightning current acting on the TS (point 3', zone $2 \mathrm{~A}$ ) of thickness $h=1.5 \mathrm{~mm}$

$\left(I_{m D}=-8.08 \mathrm{~V} \times 12625 \mathrm{~A} / \mathrm{V}=-102 \mathrm{kA} ; t_{m D}=20 \mu \mathrm{s}\right.$; $\left.J_{D}=0.26 \cdot 10^{6} \mathrm{~A}^{2} \cdot \mathrm{s}\right)$

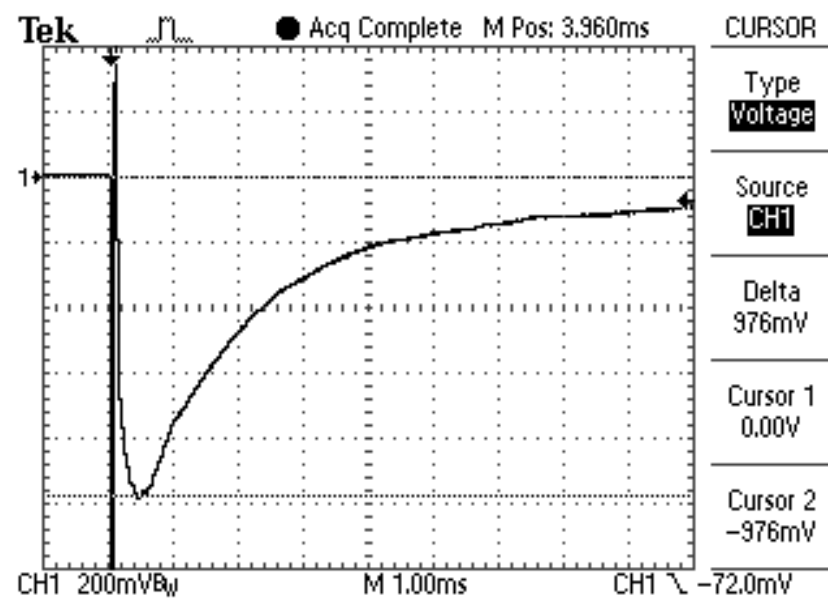

Fig. 14. Oscillogram of the intermediate $B$ - component of the lightning current acting on the TS (point 3', zone 2A) of thickness $h=1.5 \mathrm{~mm}$

$\left(I_{m B}=-0.976 \mathrm{~V} \times 6312 \mathrm{~A} / \mathrm{V}=-6160 \mathrm{~A} ; I_{L B}=q_{B} / \tau_{p B}=-2366 \mathrm{~A}\right.$; $\tau_{p B}=5 \mathrm{~ms} ; q_{B}=-11.83 \mathrm{C}$ )

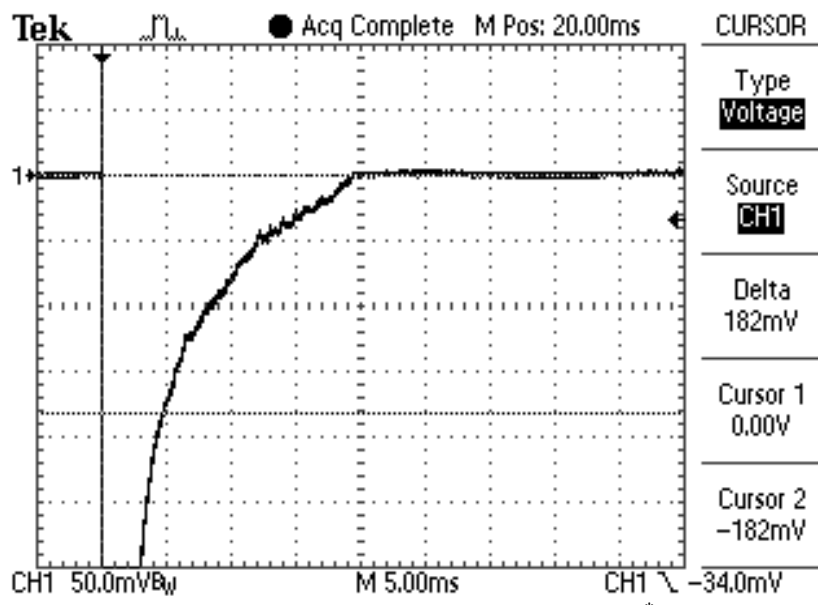

Fig. 15. Oscillogram of the shortened long-term $C^{*}$ - component of the lightning current acting on the TS (point 3', zone 1A) of thickness $h=1.5 \mathrm{~mm}$

$\left(I_{m C^{*}}=-0.182 \mathrm{~V} \times 6312 \mathrm{~A} / \mathrm{V}=-1148 \mathrm{~A} ; I_{L C^{*}}=q_{C^{*}} / \tau_{p C^{*}}=-416 \mathrm{~A}\right.$; $\tau_{p C^{*}}=14.8 \mathrm{~ms} ; q_{C^{*}}=-6.16 \mathrm{C}$ )

The application at the final stage of the research carried out to the tested for thermal lightning resistibility in zone $2 \mathrm{~A}$ in the discharge circuit of the UITOM-1 installation for a panel sample of high-strength aluminum alloy grade B95 with thickness of $h=1.5 \mathrm{~mm}$ of the method of capillary control of the damage site of the TS from a direct impact of the channel of simulated lightning confirmed its through penetration.

Figure 16 shows the results of direct action for zone $1 \mathrm{~A}$ on the TS of a flat duralumin panel with thickness $h=1.2 \mathrm{~mm}$ of the aircraft's fuel tank of the corresponding artificial lightning current components with normalized ATPs. It is clearly seen that such an effect on the TS of the simulated at the LCG type UITOM-1 type the lightning discharge channel leads to through penetration of the wall of the duralumin panel of the aircraft's tank in the place of its (channel) binding on the outer surface of the TS. Here, the ATPs of the components of the artificial lightning current recorded in DSO for zones $1 \mathrm{~A}$ and 2A did not differ significantly from the numerical data characteristic of their oscillograms shown in Fig. 9-11, 13-15.

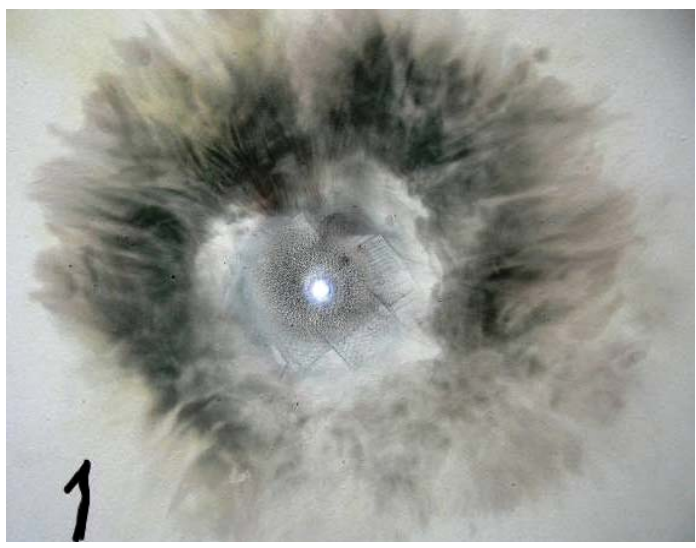

Fig. 16. General view from the binding zone on the outer surface of the TS of a flat duralumin panel $(h=1.2 \mathrm{~mm})$ of the aircraft's fuel tank of the plasma channel simulated by the UITOM-1 installation of a lightning discharge of the results of direct exposure to this TS for zone 1A of the normalized components of the artificial lightning current, characterized by through local penetration of the TS panel wall at the point of impact of the lightning channel 
Note that this through penetration from the direct thermal action of the plasma channel of the simulated lightning discharge of the wall of a flat duralumin panel with thickness $h=1.2 \mathrm{~mm}$ of the aircraft's fuel tank (see Fig. 16) is unambiguously indicated by as the results of photographic recording of thermal sparks with an insulating pyramidal LTC from internal surface of the TS, as well as by the calculated estimation by (5) of the depth $r_{k}$ and by (4) of the radius $r_{k}$ of the hole for its penetration.

Figure 17 shows the results of direct thunderstorm discharges effect simulated on the LCG type UITOM-1 with normalized values of the ATPs of their current components for zone $1 \mathrm{~A}$ to a wall with thickness of $h=1.2 \mathrm{~mm}$ of the TS from the side of its inner surface. The experimental data shown in Fig. 17, confirm the conclusion that the TS with the necessary protective coatings of a panel made of an aluminum alloy of grade B95 with thickness $h=1.2 \mathrm{~mm}$ of the aircraft's fuel tank for zone 1A does not satisfy condition (1) and is thermally unstable to direct action on it of $A-, B$ - and $C^{*}$ - current components of artificial lightning with ATPs normalized according to $[3,4]$.

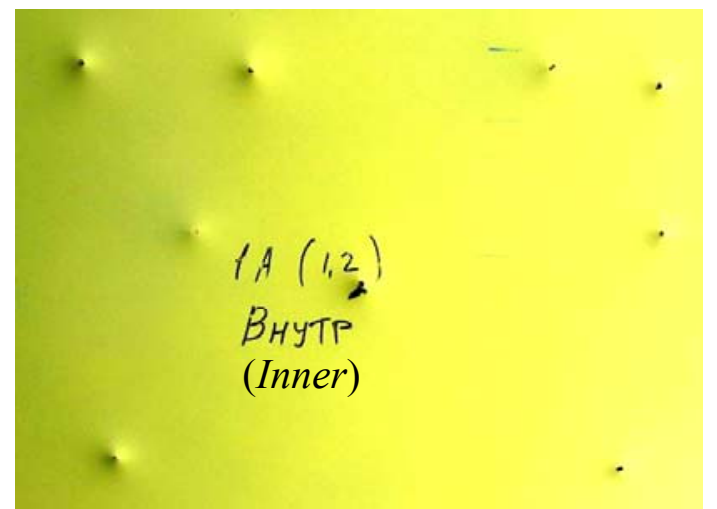

Fig. 17. General view of the TS of a flat duralumin panel $(h=1.2 \mathrm{~mm})$ of the aircraft's fuel tank from the side of its inner surface, the outer surface of which at various points in the discharge circuit of the UITOM-1 type installation was subjected to direct impacts of pulsed components of artificial lightning current corresponding to zone $1 \mathrm{~A}$

\section{Conclusions.}

1. The results of the calculation-experimental investigations carried out at the Scientific-\&-Research Planning-\&-Design Institute «Molniya» of the National Technical University «Kharkiv Polytechnic Institute» regarding the thermal resistibility of prototypes with required by technological conditions protective coatings of flat rectangular panels of a fuel tank with size of 550 $\mathrm{mm} \times 800 \mathrm{~mm}$ and thickness $h$ from 1.2 to $4 \mathrm{~mm}$ made of high-strength aluminum alloy of brand B95 of the designed domestic aircraft to direct impact on them according to the current requirements of US regulatory documents SAE ARP 5412 and SAE ARP 5416 of $A-, B$ and $C^{*}$ - components of the current of artificial lightning (1A zone), as well as $D$-, $B$ - and $C^{*}$ - components of the artificial lightning current (zone 2A) with normalized ATPs indicate that the studied panels with thickness $h=1.2 \mathrm{~mm}, h=1.5 \mathrm{~mm}$ and $h=1.8 \mathrm{~mm}$ for zone $1 \mathrm{~A}$, as well as with thickness $h=1.2 \mathrm{~mm}$ and $h=1.5 \mathrm{~mm}$ for zone $2 \mathrm{~A}$ are thermally unstable $\left(h \leq h_{k}\right)$ to direct impacts in them of a plasma channel of a lightning discharge simulated under laboratory conditions with the used components of a pulsed current of artificial lightning.

2. The thermal lightning resistibility of the studied panels with thickness $h$ of the aircraft's fuel tank is determined by the ATPs of the shortened long-term $C^{*}$ current component of the artificial lightning, which causes the appearance of rounded penetration holes with radius $r_{k}$ and depth $h_{k}$ in them. To find the values of $r_{k}$ and $h_{k}$ in the indicated panels of the aircraft's fuel tank, struck in the earth's air atmosphere by a direct impact of a simulated lightning discharge in them, approximate calculated relationships (4), (5) are recommended. The operability of these relationships is confirmed by the results of field experiments performed using a powerful generator of pulsed current of artificial lightning of the UITOM-1 type.

3. In the event of a direct impact on a plane in an air atmosphere of a lightning plasma channel with normalized ATPs of the indicated components of its pulsed current, to prevent ignition of fuel vapors in the tank under study with walls made of high-strength aluminum alloy grade B95 and corresponding doublesided protective coatings of the designed aircraft and its accident, the thickness $h$ of the wall of this fuel tank must be at least $1.8 \mathrm{~mm}$ when the tank is located in zone $2 \mathrm{~A}$ of its lightning strike and at least $2 \mathrm{~mm}$ the tank is located in zone $1 \mathrm{~A}$ of its lightning strike.

\section{REFERENCES}

1. Yuman M.A. Molniya [Lightning]. Moscow, Mir Publ., 1972. 327 p. (Rus).

2. Uman M.A. Natural and artificially-initiated lightning and lightning test standards. Proceedings of the IEEE, 1988, vol.76, no.12, pp. 1548-1565. doi: 10.1109/5.16349.

3. SAE ARP 5412: 2013. Aircraft Lightning Environment and Ralated Test Waveforms. SAE Aerospace. USA, 2013. - pp. 1-56. 4. SAE ARP 5416: 2013. Aircraft Lightning Test Methods. SAE Aerospace. USA, 2013. - pp. 1-145.

5. Baranov M.I., Koliushko G.M., Kravchenko V.I., Nedzel'skii O.S., Dnyshchenko V.N. A Current Generator of the Artificial Lightning for Full-Scale Tests of Engineering Objects. Instruments and Experimental Technique, 2008, no.3, pp. 401405. doi: 10.1134/s0020441208030123.

6. Baranov M.I., Buriakovskyi S.G., Rudakov S.V. The tooling in Ukraine of model tests of objects of energy, aviation and space-rocket engineering on resistibility to action of pulsed current of artificial lightning. Electrical engineering \& electromechanics, 2018, no.4, pp. 45-53. doi: 10.20998/2074272X.2018.4.08.

7. Baranov M.I. Izbrannye voprosy elektrofiziki. Monografiya $v 3 \mathrm{kh}$ tomakh. Tom 2, Kn. 2: Teoriia elektrofizicheskikh effektov $i$ zadach [Selected topics of Electrophysics. Monograph in 3 Vols. Vol.2, Book 2. A theory of electrophysical effects and tasks]. Kharkiv, Tochka Publ., 2010. 407 p. (Rus).

8. Knopfel' G. Sverkhsil'nye impul'snye magnitnye polia [Ultra strong pulsed magnetic fields]. Moscow, Mir Publ., 1972. 391 p. (Rus).

9. Raiser Yu.P. Fizika gazovogo razryada [Physics of gas discharge]. Moscow, Nauka Publ., 1987. 592 p. (Rus).

10. Kuhling H. Spravochnik po fizike. Per. s nem. [Dictonary on Physics. Translated from German]. Moscow, Mir Publ., 1982. 520 p. (Rus).

11. Baranov M.I., Nosenko M.A. Influence of the thermal action of artificially-initiated lightning current on specimens of the 
metal skin of an aircraft. Journal of Engineering Physics and Thermophysics, 2009, vol.82, no.5, pp. 978-987. doi: 10.1007/S10891-009-0272-z.

12. Baranov M.I., Kniaziev V.V., Rudakov S.V. Calculation and experimental estimation of results of electro-thermal action of rationed by the international standard IEC 62305-1-2010 impulse current of short blow of artificial lightning on the thinwalled coverage from stainless steel. Electrical engineering \& electromechanics, 2017, no.1, pp. 31-38. doi: 10.20998/2074272X.2017.1.06.

13. IEC 62305-1: 2010 «Protection against lightning. Part 1: General principles». Geneva, IEC Publ., 2010.

14. Available at: https://en.wikipedia.org/wiki/Duralumin (accessed 20 May 2018).

15. Available at: https://znanija.com/task/26630096 (accessed 10 June 2018).

16. Abramov N.R., Kuzhekin I.P., Larionov V.P. Characteristics of penetration of the walls of metal objects when exposed to lightning. Electricity, 1986, no.11, pp. 22-27. (Rus).

17. Baranov M.I., Buriakovskyi S.G., Rudakov S.V. The metrology support in Ukraine of tests of objects of energy, aviation and space-rocket engineering on resistibility to action of pulses of current (voltage) of artificial lightning and commutation pulses of voltage. Electrical engineering \& electromechanics, 2018, no.5, pp. 44-53. doi: 10.20998/2074272X.2018.5.08.
18. Baranov M.I., Kniaziev V.V., Rudakov S.V. The coaxial shunt for measurement of current pulses of artificial lightning with the amplitude up to $\pm 220 \mathrm{kA}$. Instruments and Experimental Technique, 2018, vol.61, no.4, pp. 501-505. doi: 10.1134/S0020441218030156

19. Baranov M.I., Rudakov S.V. Electrothermal action of the pulse of the current of a short artificial-lightning stroke on test specimens of wires and cables of electric power objects. Journal of Engineering Physics and Thermophysics, 2018, vol.91, no.2, pp. 544-555. doi: 10.1007/s10891-018-1775-2.

Received 27.03.2019

M.I. Baranov ${ }^{1}$, Doctor of Technical Science, Professor,

S.G. Buriakovskyi ${ }^{1}$, Doctor of Technical Science, Professor,

A.S. Hrytsenko ${ }^{2}$, Lead Research Engineer,

V.A. Kostiuk ${ }^{2}$, Chief Designer,

${ }^{1}$ Scientific-\&-Research Planning-\&-Design Institute «Molniya», National Technical University «Kharkiv Polytechnic Institute», 47, Shevchenko Str., Kharkiv, 61013, Ukraine, phone +38057 7076841,

e-mail: baranovmi@kpi.kharkov.ua, sergbyr@i.ua

${ }^{2}$ Antonov Company,

1, Akademika Tupoleva Str., Kyiv, 03062, Ukraine, phone+38 044 4543233, e-mail: info@antonov.com

How to cite this article:

Baranov M.I., Buriakovskyi S.G., Hrytsenko A.S., Kostiuk V.A. Results of investigations of thermal resistibility of prototypes of aluminum alloy panels of fuel tank of airplane to direct action of normalized components of artificial lightning current. Electrical engineering \& electromechanics, 2019, no.6, pp. 29-38. doi: 10.20998/2074272X.2019.6.04. 